\title{
Efforts to Increase Public Welfare Consciousness Through Pay Zakat Rice Crop
}

\author{
Nasri Hamang \\ State Islamic High School, \\ Pare-Pare, South Sulawesi, Indonesia. \\ nasrirasma@gmail.com
}

\author{
Irmayani \\ Universitas Muhammadiyah Parepare, \\ Parepare, Indonesia \\ irmaumpar@yahoo.co.id
}

\author{
Amaluddin \\ Universitas Muhammadiyah Parepare, \\ Parepare, Indonesia. \\ amaluddin1965@gmail.com
}

\begin{abstract}
This paper examines and discusses how to improve people's welfare Pinrang, South Sulawesi through an awareness for rice farmers in paying zakat rice yields. Pinrang a rice-producing districts are very large by the amount of rice area is very spacious. If this huge income collected zakat on it regularly according to the provisions of law, it will be the welfare of the community on an ongoing basis. But it is unfortunate that the government Pinrang, especially paddy rice farmers have not yet realized the potential of this well. Therefore, both parties need to be encouraged to watch her perform concrete measures and strategic. The scholars need to develop programs that could encourage the government to realize coordinated the payment of zakat and paddy rice farmers to pay Zakat regularly. Efforts of the scholars as nonformal leaders, in turn, will make the government committed coordinate and paddy rice farmers understand and accomplish it with full awareness and in turn will feel her contribution to the public welfare.
\end{abstract}

\section{Keywords-The welfare of society; consciousness of paying zakat; role of the clergy.}

\section{INTRODUCTION}

One of the important instruments to the public welfare and prosperity of the country is zakat. Zakat is an Islamic teachings which became the foundation of economic ideal of Muslims. Theories in the teachings of charity is able to organize an economy and the welfare of the community. Zakat in fact, in passing equal to the tax levied all over the country, so in English, some Western writers (non-Muslims) called Islamic taxation or tax religious fervor, but among scholars generally call alms (Almascatie, 1983). Zakat is mandatory for
Muslims as well as taxes for the people, is intended to eliminate the evil in people's lives. One of the grace of God to man is that $\mathrm{He}$ made man as inheritors of the earth by supplying them with Shari'a charity that people's lives will be orderly and happy, free from mudharat, both social and economic mudharat (Sha'rawi, 2010).

Doctrine zakat to the teachings of the economy and welfare that have a character much different from the two economic doctrine known and practiced by the majority of citizens the world over the years, namely socialism and capitalism. Oemar Haji Said Tjokroamonoto, founder of the organization Syarikat Islam in his book titled Islam and Socialism, written in November 1924 stated, the key points of socialism and capitalism is the exploitation of a person against another person. Therefore Islam was the enemy of capitalism. Capitalism, against humanity, but it was Also not in accordance with God's will as written in the Qur'an, one of the solution to the problems created by capitalism, he emphasized, was by distributing wealth through the institution of Zakat (Alms). Zakat is the antithesis of socialismcommunism on the movement, and simultaneously asserts, Islam has a unique concept of socialism. Zakat itself would then have an additional meaning since through this social equality and solidarity Among would emerge. Equality in this sence meant that there would be excess accumulation of wealth by certain people in society. Solidarity meant that mutual assistance would emerge among muslim (Arifin, 2000).

Zakat as one of the pillars of the five pillars of Islam that is not true when it is merely a ritual teachings. Zakat is basically a religious doctrine that is ritual, the same time social and economic nature; or in other words, it is a socio-economic religious teachings. In this case, a religious doctrine that is social and economic nature. The Islamic Muhammadiyah 
Organization states that zakat is not only a religious duty, but Also has on important social function in that it increases the social welfare. Based on this idea, the movement thinks that is important to coordinate the distribution of zakat funds so that it be given to Reviews those who have the right to receive it. The movement had corrected the distribution of zakat roommates tended to accumulate to the advantage of a single person. To this end, the movement established a temporary community to receive and to distribute alms. The function of this committee, later merged into the Muhammadiyah`s Social Welfare and Health Care (January, 1992).

One type of Islam is zakat introduced zakat agricultural products or crops, such as rice. These types of zakat potential given the earth was created by God with a relatively broad one main function is to be a means of cultivation for humans. Results of crop farming, particularly areas that have extensive rice area, become a source of potential public welfare. Privileged or advantages earth as a means of farming potential to bring prosperity to people, one of which is that it is natural that does not contain economic risk or loss for the owner. Earth will never be diminished or shrinking and declining productivity potential, even more will increase with the improved development capabilities potential human sciences to fertilize.

\section{METHOD}

This study was conducted in Pinrang District, South Sulawesi, Indonesia from May to September 2015. The purposive sampling carried out at farmers who cultivate rice paddies certain area according to the rules of zakat in Islam, which has a rice area of approximately 60,000 ha to 50,000 technical irrigated ha and 10,000 ha of rain fed (irrigation Department Pinrang, 2015). The approach of this research is purposive sampling to select farmers who cultivate paddy rice dal described in qualitative analysis.

\section{RESULT AND DISCUSSION}

1. The existence of Amil Zakat Board Pinrang

Zakat as pillars of Islam and the amount of zakat potential in Indonesia, the government issued a regulation successive Joint Decree of the Minister of Religious Affairs and the Minister of Home Affairs No. 29 and No. 47 of 1991, Act No. 38 of 1999 and Law No. 23 on the Management zakat. One of the essential content of this Act is the establishment of the management body in charge of managing zakat called Amil Zakat Board National, abbreviated BAZNAS. The management bodies should form start level Centre up to district level, even be equipped with Zakat Implementation Unit (UPZ) reached the level of the Village and the Village as well as the mosque. The formation or presence of this body is certainly expected to work professionally and maximum in collecting and distributing zakat, so as to help the government to accelerate the realization of community welfare.

Amil Zakat Board Pinrang since its establishment in 1995 until now appeared to be not able to do the maximum, as trustee or expectation Act Zakat, because of limited resources, both facilities and infrastructure resources and human resources. Amil Zakat Board new Pinrang capable of holding facilities and infrastructure in a simple and robust management at the district level. Amil Zakat Board district level have not been able to form a strong management bodies in all districts, let alone get to the village and village level as well as mosques at once with adequate facilities and infrastructure. As a result the public at large, including the farmers have not known the existence of Amil Zakat.One proof of the inability of Amil Zakat Board Pinrang working professionally and maximum, among others, can be seen in the amount of data entry zakat on paddy crop per-January till the August 2014 is IDR 138.678.000 (One Hundred Thirty Eight Million Six Hundred Seventy Eight Million) (Report of the Agency Amil Zakat Pinrang 2014).

In an effort to raise awareness among farmers to pay zakat yield rice crops, Amil Zakat Board Pinrang encouraging and directing board Implementation Unit Zakat (UPZ) throughout the Village and the Village as well as mosques to cooperate with the Chairman of Farmers Group in conducting outreach to farmers. In this case, when the Chairman of Farmers Group will perform counseling agricultural issues, such as the growing season, the selection of rice seedlings, provision of fertilizers and drugs, and so on, when it was also caretaker UPZ ask occasions and special events to convey and explain the program UPZ and problems associated with the charity. In carrying out this task is expected to appear as the spearhead of the program's success Amil Zakat Board District.

2. Role of ulama in existence socializing doctrine zakat

Social scientists introduced, there were three theories about the right of ownership. First, a natural right as a fundamental right, although cause open question, whether it conforms to the requirements or demands of the natural law. Second, the theory of basing ownership on the model or revenue sources, which, for example through employment or value of the product. Thirdly, there is a theory based on the right of ownership, like any other right, but tested by contributing to the public good or of mankind (Ginsberg, 2003). Most farmers in the paddy rice Pinrang seems to embrace the first theory. They like the view that the fields that they have a natural right given to him to be the means and the development of life that should not be interfered with another person or party. Person or party who tries to interfere by reducing the entitlement to judgment, will be resisted to extremes, either in the form of coarse or fine of up undiminished in the slightest, including such as the zakat collection.

Farmers rice on Pinrang should embrace the third theory, a theory which teaches that the understanding that in private property rights, no property rights of others. This theory is consistent with the theory taught al-Qur'an fifteen centuries ago. Allah says in Surah al-Dzariyat (51): 19: And in their wealth there is a right for (the poor) are requested and the poor who have no share (which does not beg. Farmers in Pinrang 
must understand that in rice yields they earn every season, there are public rights, namely the rights of poor people, the poor, amyl, converts, people owe, bondsmen, sabilillah and ibn sabil. this right can be referred to as a human right of religious in the economic field, which means farmers should not be ignored. But what happened that turns out most of the farmers did not execute it (BAZNAZ Pinrang, 2015).

Pinrang society's view on generally, including farmers about zakat are as follows: 1. The majority do not judge or look, especially zakat, not as important as the other pillars of Islam. 2. The majority are not willing to implement and cultivate zakat as zakat fitrah. 3. The majority do not understand well the function of social, economic and welfare charity teachings. 4 . The majority do not know the weight in the next threat if it does not give charity. 5. The majority do not know the laws or provisions of zakat (Sanusi, 2015).

In connection with the attitude of farmers Pinrang the role of the clergy is necessary to change it. mufti is highly demanded to give them understanding of the position and the existence of zakat teachings. mufti as someone who feared God, scientists rhythm of knowledge and actions as evidenced by chastity, obedience and sincerity in worship (Thanthawi, 1991), in the social context of Indonesian culture in general, is the leader of non-formal heard and followed their opinions and words, Although the scholars are EXCLUSIVELY known as religious leaders, Reviews their relations with villages are multi-faceted, and include social, educational, political and economics Often features (Mansurnoor, 1987).

There are at least three things that must be urgently promoted, namely (1) the unification of the practice of prayer and zakat, (2) a threat to those who do not give zakah, and (3) the promise of God against which give charity. Whereas in alQur`an, verses about prayer always goes to charity. That means, the practice of prayer should be coupled with the practice of zakat. Salat and Zakat are the two pillars of Islam which is a typical form of worship to God and spending wealth in the way of God (al-Thabathaba i, 1991). While the threat to those who do not give zakah, God says in Surah alTawbah (9): 34-35 - translation: $O$ ye who believe, in fact largely from those pious Jewish and Christian monks actually eat treasure people with the vanity and they hinder (men) from the path of Allah. And those who hoard gold and silver and spend it not in the way of Allah: announce unto them, (that they will get) a painful punishment (34). On the day of heated gold and silver was in Hell, and burned with their foreheads, stomach and their backs (and said) to them: This is your possession ye buried for yourselves, so taste now (due to) what you save it (35). The promise of God against which give zakah, God says in Q. S. Saba` (34): 39 - Translation: And what items you expense (alms; zakat), then God will replace them, and He is the giver of sustenance as well as possible. $Q$. S. al-Tawbah (90): 105 asserts, God will replace it with a double (al-Zamaksyari, 1964). Therefore, farmers should not behave like this time, which did not sit zakat as important as prayer, cause or charity as pillars of Islam pillars collapsed (Bewley, 2001). Most devout praying, even fasting and Hajj, but do not obey pay zakat.
3. Role of Government in handling coordinated the Zakat

The Government has a position and a significant presence of drawing coordinated the maximum, effective and efficient. Even syar'i, the Heads of State or Government shall organize charity by raising certain people to handle it. Surah al-Tawbah (9): 103 suggests, God commanded His Messenger to take zakat to them (which is capable of and repentance), in order to cleanse them of their sins and raised avarice of the selves they (al-Jaziri, 1992). Prophet. As the head of state (Daulah Medina) has done just that. In one narrated by Bukhari and Muslim from Abu Huraerah reported that the Messenger of Allah. Has commissioned a man named Umar ibn Luthbiah as zakat collector. The Caliph after the Prophet. had also done the same thing.

In addition, there are several reasons why the government should immediately acts as zakat management coordinator which is as follows:

1. The fact is, that in the Muslim people can afford, there are people who avarice miser showed by refusing to pay zakat. Because it requires zakah officers of the State have adequate rights to force them to pay zakat.

2. The number of Muslims who meet the required criteria zakat in every Muslim society, relatively numerous and will increasingly multiply significantly over time. It was, of course it requires officers institutionalized zakat, permanent and professional.

3. Governments have a duty and responsibility to uphold justice in all fields, including social justice or fairness in society. One important instrument of social justice is zakat, which only the government who is able to enforce it.

4. The government was seen authoritative in cleansing the soul muzakki of properties that can undermine the sacred values of zakat, such as personal interests, arrogant and feel as the best or the greatest. Zakat is paid muzakki can achieve the criteria as zakat payment that renders obligations as well as gain the reward.

5. Most people have a mentally very loved treasures, which are therefore very heavy issue a part of that. If the sovereign, when the payment of zakat was handed to each person based on his own consciousness and without government interference, undoubtedly many people who ignore it obligatory zakat.

6. Poor who receive zakat payment of zakat body feeling of inferiority, because maintained from humiliation and the possibility of painful words of the rich, if it received it directly. The rich man sometime easy to deride people who had given alms.

7. When implementing zakat obligatory alms handed over to itself, it would be injustice or inequality against mustahik, because everyone (muzakki) will have their own views and judgment or certain motives to someone (mustahik). As a result, most likely there mustahik who do not get that part at all, while others gained the part of many. 
8. Group entitled to zakat is not only individuals who certain, such as the poor, but some classes (ashnaf) Other, which also wholly the responsibility of the government to pay attention.

9. Government for the management of zakat in his authority, which, if the country in a state of dire need of funds for the benefit of the development of facilities, he easily took the funding of zakat.

Government with certain considerations, such as the obligatory zakat being adamant not want to pay zakat, while already knowing the law as compulsory, it is justified to take action at home, until they pay zakat, either willingly or forced. Prophet. said which means: I ordered to fight the people until they testify that there is no god but Allah, establish prayer and give alms. When they have done so that, they have kept their blood and treasure. However when they violate the rules of Islam, then the calculation submitted to Allah (H. R. Muslim from Abdullah ibn Umar).

The first Caliph, Abu Bakr al-Siddiq, during the caliphate, has been firmly persist in the fight against people who are reluctant to pay his zakat, although it has made a creed, there is no god but God; and his main companions Umar did not approve. One story reported that when the Prophet died and Abu Bakr al-Siddiq rose to Caliph, Abu Bakr al-Siddiq said: Ubiquitous Arab apostate, I will fight. Umar replied: How do you want to fight them, but the Prophet once said, who has pledged no God but Allah, he is effectively maintained and soul of my treasures. Abu Bakar said again: By God, I will fight those who differentiate prayer with the charity. Indeed, charity is an obligation of the treasure, for the sake of God, if they do not want to give a kid like that they've given to the Prophet as zakat, my fight will undoubtedly result would not surrender again (Sabiq, 2000). A history of the report, Abu Bakar al-Siddiq with her friends, has been under the pretext of combating them, who would not give zakah means has from Islam (apostate) and classified was kosher blood.

Pinrang the government has committed to handle the zakat coordinated and organized, must insist and in a planned real effort in realizing it. What has been proclaimed as was done in the village Labolong in 2014 ago by inviting leaders rice farmers, the Imams of Mosques and rogue elements of government officials, although it has not received a satisfactory, mainly from farmers, should be continued until the time gets good reception (Public Welfare Administration Regional Secretariat Pinrang, 2014). Farmers and land owners should not be allowed not to pay Zakat regularly as the provisions of the Shari'a. The government should strongly feel guilty and also looked very innocent of the land owners and farmers in a protracted not give charity. The government should have an understanding, that by handling it in an organized charity officially the resumption of what was undertaken Prophet Muhammad.

Pinrang which has technical irrigated rice acreage through giant dams fort, $10 \mathrm{~km}$ north of the city Pinrang 50,000 ha (Department of Agriculture Pinrang), no doubt as a district that is able to reach the level of prosperity of society which is relatively very high. With the planting season twice a year and the average income tare 5 tons per hectare, which means $5 \mathrm{x}$ 50,000 , the number of overall production is 250,000 tons. 250,000 tons of this amount, if judged in rupiah with the price of grain per 1 ton (Now) Rp. 3. 300. 000, which means that $250,000 \times$ Rp. 3,300,000, then the result is Rp. 825 billion. This amount is the per-6 (six) months or one growing season, which means the PER-1 (one) year or two cropping seasons is $2 \times \mathrm{Rp} 825$ billion = USD 1.650.000.000.000 (One Hundred Fifty Six Trillion billion). With the results of Rp. The 825 billion-per-6 (six), if levied zakat amounting to $5 \%$ as the provisions agreed scholars zakat, then $5 \%$ x Rp. 825 billion, meaning the amount is Rp. 41.25 billion (Forty-one Billion Two Hundred and Fifty Million). So if the two season or one year, then the amount of zakat is $2 \mathrm{x}$ This amount is the amount of per-6 (six) months or one growing season, which means the PER-1 (one) year or two cropping seasons is $2 \mathrm{x} \mathrm{Rp}$ $\mathrm{Rp}, 41.25$ billion $=\mathrm{Rp} 82.5$ billion (Eighty Two Billion Five Hundred Million).

Zakat yield rice crops that, if managed professionally and maximum government, then Pinrang will be a district such as the Islamic lands in the days of the Caliphate. That turned out to be the practice of zakat withdrawals that have been made in the Islamic state throughout its history, has successfully led the country and people in achieving glories. The state policy in the withdrawal of zakat, a huge influence on people's lives, in the fight against poverty and to break down the roots of misery and underdevelopment. Through practice withdrawal policy zakat, the Muslim community from the farthest limits to the extent most distant others, that people become sufficiently alive and help each other. Nobody among the sons of daughters who get help from the Baitul Mal and from the rich (Ulwan, 1986).

If the government Pinrang work optimally manage zakat and paddy rice farmers Pinrang have the awareness to give charity, surely the existence of the teachings of charity as a source of public welfare will be realized in the middle of the community. As said the author of the book-Kitan scholars of jurisprudence, that if the Muslim zakat collected and distributed according commanded by Allah in al-Qur'an, undoubtedly will have enough pauper, a fool will knowledgeable, widowers will have wives, orphans will get education, parents and kids will be happy, the mosque became prosperous, madrasahs, clinics, hospitals would stand, there would be no thieves, prostitutes and no one will be oppressed difficulty necessities of life (al-Baihami, 1993).

Governments that manage zakat professionally and maximum historically proven that in a relatively short time is able to deliver all of his people mencapaik prosperous life. Yahya bin Said has said Rasyidah 5th Caliph, Umar ibn Abd. Aziz has sent to Africa to collect zakat, then I picked from the population, then I look for poor people to give him charity which I have collected, but I could not find a single indigent person who should take them, because the Caliph Umar ibn Abd. Aziz has been insufficient consciousness of the people, therefore, have I collected zakat, I gave to the servant-slave, then I gave him his freedom. (Ulwan, loc. Cit). Yahya bin Said said anyway, some farmers in Syria has told me, that the 
agricultural output in Syria could provide income to charity each year, funds amounting to 600,000,000.00 (Six Hundred Million) Syrian lira. Conceivably, when combined with the results of the agricultural zakat results from other sources such as the type of merchandise, type of zakat money and other types of zakat, the result amounted to exceed our picture. Many of them it is definitely enough to decide triumvirate very scary roots in society, namely poverty, ignorance roots and root diseases. Even the amount of assistance it can provide sufficient guarantee of life for individuals, so that they can feel social justice in Islam.

Treasure paid zakat is able to bring to the well-being because he would awake or lasting because getting stopped and the grace of God. Islam emphasizes, property will be maintained is the wealth that gets stopped and the grace of God with the indicator as follows: 1 . The more he grew, the more bring their owners also increased gratitude to God in the form of, among others, give alms. 2. Making owners closer to God causing her more love and feel the suffering of poor people as he moved to give alms that many sincerely to them. 3 . The owners of property that is paid zakat will be protected by God owners of any possible acts of abuse causes more will be maintained. (Masqood, 190).

Local revenue collection assumptions Pinrang through zakat relatively very large, the government Pinrang not only able to help citizens who are unable to meet their daily needs consumptive were able to establish many sources of economic and strategic state revenue. The government was able to establish Hospital with free medical care, which is in a sense the patient does not pay a dime, but the doctor and the manager of the hospital continued to receive salaries through Zakat funds. The government is able to set up a scholarship in large numbers for the sons of the area who want to continue their education to a higher level. The government was able to establish the efforts of industry and the economy as a means of public employment and a source of local revenue, and so forth. Pinrang in turn can grow as well as bringing forward prosperity of its citizens achieve a prosperous life and unseen.

\section{CONCLUSION}

Pinrang with rice acreage holdings relatively broad, to be producing areas of rice plants, or rice are very large as well as a large zakat potential anyway. If the results of paddy or rice are very large, the farmers have to pay Zakat awareness at the same time being able to manage a maximum governments and professionals, it will encourage the growth rate of the economy and the welfare of the people is very high. By counting the results of 250,000 ton-per- 6 (six) months or one growing season or 500,000 tons per year, then the amount of zakat is Rp. 41.25 billion (Forty-one billion two hundred fifty million rupiah) per-6 (six) months or Rp 82.5 billion (Eighty Two Billion Five Hundred Million Rupiah) per 1 (One Year). Zakat fund of this magnitude, the government can freely make program development and welfare of the community in a sustainable manner.

\section{ACKNOWLEDGMENT}

Thank you so much for State Islamic High School, ParePare for the support this article. For all out team work Ms Irmayani, Mr Amaluddin for good cooperation. Specially Muhammadiyah University of Parepare to realized this article.

\section{REFERENCES}

[1] Abdul Rahim Abdul Rahman (2005), "Menangani Cabaran Semasa Institusi Zakat", dalam Abdul Halim Mohd Nor (ed.), Isu-isu Kontemporari Zakat di Malaysia, Vol. 1, Melaka: Institut Kajian Zakat Malaysia (IkaZ).

[2] Al-Thabathaba i, Husain, Muhammad, al-Allama al-Sayyid, al-Allama (1991/1411), al-Mizan fi Tafsir al-Qur`an, Cet. I; Beirut-Lebanon: Muassisah al-'Alami li al-Mathbu'at: 389.

[3] Department of Agriculture, Livestock and Forestry Pinrang (2015). Board Data Area of Wetland.

[4] Ginsberg, Morris (w, y) On Justice in Society; Indonesia Edition: Justice in Society: 81-82.

[5] Jainuri, Achmad (1992). The Muhammadiyah Movement in TwentiethCentury Indonesia: A Socio Religious Study; Montreal: McGill University: $81-82$

[6] Malay, Arifin, Hasnul (2000). Islam and Politics in the Thought ofTjokroaminoto 1882-1934, USA: Institute of Islamic Studies McGill University: 52-53.

[7] Mansurnoor, Arifin, Iiklik (1987). Ulama, Village and Change: Islam and Central in Madura; Montreal: Institutes os Islamics Studies McGill University: 371 .

[8] Sanep. A, Hairunnizam.W, Adnan. M. Penswastaan Institusi Zakat dan Kesannya terhadap Pemayaran Secara Formal di Malaysia. IJMS 13 (2), 175-196 (2006). Pusat Pengajian Ekonomi. Universitas Kebangsaan Malaysia.

[9] Sha'rawi, Muwalli, Muhammad (t, th). Jurnal Tafsir al-Sha'rawi, Jlid IX, Cet. I; Egypt: Akhbar Al-Yaum: 5421-5422. 